\title{
mRNA expression of the long and short forms of uncoupling protein-3 in obese and lean humans
}

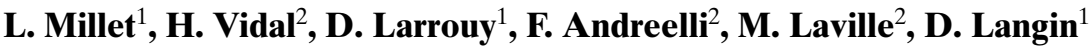 \\ ${ }^{1}$ INSERM U317, Institut Louis Bugnard, Université Paul Sabatier, Hôpital Rangueil, Toulouse, France \\ ${ }^{2}$ INSERM U449 and Centre de Recherche en Nutrition Humaine, Faculté de Médecine Laënnec, Lyon, France
}

\begin{abstract}
Summary Uncoupling protein-3 (UCP3) is a mitochondrial protein expressed in skeletal muscle, an important site of thermogenesis in humans. By uncoupling respiration from ATP synthesis, UCP3 might be involved in the control of energy expenditure. Two transcripts encoding long $\left(\mathrm{UCP} 3_{\mathrm{L}}\right)$ and short $\left(\mathrm{UCP} 3_{\mathrm{S}}\right)$ form are generated from the human UCP3 gene. $\mathrm{UCP} 3_{\mathrm{S}}$ is predicted to encode a protein which lacks the C-terminus of $\mathrm{UCP}_{\mathrm{L}}$, a region which contains motifs critical for uncoupling activity. We have investigated the regulation of $\mathrm{UCP} 3_{\mathrm{L}}$ and $\mathrm{UCP} 3_{\mathrm{S}}$ mRNAs in lean and obese humans. A specific reverse transcription-competitive polymerase chain reaction assay was developed to separately quantify the two mRNAs. Each transcript represents half of total UCP3 mRNA in 16 vastus lateralis muscle samples.
\end{abstract}

The amounts of $\mathrm{UCP}_{\mathrm{L}}$ and $\mathrm{UCP} 3_{\mathrm{S}}$ mRNAs did not differ between obese and lean subjects. The effect of fasting was studied in six lean and seven obese subjects maintained on a hypocaloric diet $(1045 \mathrm{~kJ} / \mathrm{d})$ for 5 days. Calorie restriction results in an approximately threefold increase of $\mathrm{UCP} 3_{\mathrm{L}}$ and $\mathrm{UCP} 3_{\mathrm{S}}$ mRNA levels. The induction was similar in lean and obese subjects. The data suggest that there is no major alteration of UCP3 gene expression and regulation at the level of transcription and alternative splicing in skeletal muscle of obese subjects. [Diabetologia (1998) 41: 829-832]

Keywords Uncoupling protein-3, obesity, fasting, skeletal muscle, thermogenesis.
Two new members of the mitochondrial carrier family called uncoupling protein-2 and -3 (UCP2 and UCP3) have recently been characterized [1-4]. $\mathrm{UCP} 2$ and UCP3 are postulated to play a role in energy expenditure, body weight regulation and thermoregulation. The two proteins show sequence identity with UCP1, an uncoupling protein expressed in brown adipose tissue. In rodents, but probably not to a large extent in adult humans, brown adipose tissue

Received: 9 February 1998 and in revised form: 19 March 1998

Corresponding author: Dr. D. Langin, INSERM U317, Institut Louis Bugnard, Bâtiment L3, CHU Rangueil, 31403 Toulouse Cedex 4, France

Abbreviations: UCP3, Uncoupling protein-3; $\mathrm{UCP}_{\mathrm{L}}$, long form UCP3 transcript; $\mathrm{UCP} 3_{S}$, short form UCP3 transcript; RT-competitive PCR; reverse transcription-competitive polymerase chain reaction. is a site of adaptative thermogenesis where UCP1 promotes proton transport across the mitochondrial inner membrane. Like UCP1, UCP2 and UCP3 contain six predicted transmembrane domains, mitochondrial carrier protein motifs and a potential C-terminal purine nucleotide binding domain. UCP2 and UCP3 are active at the mitochondrial level and cause, in transfected cells, a decrease in mitochondrial membrane potential. Human UCP2 and UCP3 map to the same region (q13) of chromosome 11 and the two genes are located within $100 \mathrm{~kb}$ of each other [1, $5,6]$. This location is coincident with several independently mapped quantitative trait loci for obesity and strong evidence of linkage was found between markers in the vicinity of the UCP2 and UCP3 genes and resting metabolic rate in humans $[1,7]$. UCP2 is expressed in many tissues whereas UCP3 expression seems restricted to skeletal muscle, an important site of thermogenesis in adult humans. UCP3 mRNA ex- 
ists as long and short form transcripts [3]. The two transcripts are generated from a single gene through alternative splicing and use of polyadenylation signals [6]. The short form transcript encodes a putative protein, designated $\mathrm{UCP}_{\mathrm{S}}$, that does not contain the last 37 amino acids present in the long form UCP3 transcript $\left(\mathrm{UCP} 3_{\mathrm{L}}\right), \mathrm{UCP} 1$ and $\mathrm{UCP} 2$. This region is likely to contain motifs and residues critical for uncoupling activity. In a recent study, we have investigated, in humans, the regulation of total UCP3 mRNA level without discrimination between the two transcripts [8]. Fasting resulted in a similar induction of UCP3 gene expression in lean and obese subjects. In the present study, a specific reverse transcriptioncompetitive polymerase chain reaction assay (RTcompetitive PCR) was set up to quantify the levels of each transcript in order to determine whether $\mathrm{UCP} 3_{\mathrm{S}}$ and $\mathrm{UCP} 3_{\mathrm{L}}$ mRNA levels differ between lean and obese subjects and are differently regulated during fasting.

\section{Subjects and methods}

Subjects. The subjects comprised nine lean (three men and six women, mean age \pm SD $50 \pm 5$ years) and seven non-diabetic obese (two men and five women, mean age \pm SD $43 \pm 4$ years) people. Obesity was defined as a BMI higher than $27 \mathrm{~kg} / \mathrm{m}^{2}$. Obese subjects had maintained a stable body weight for at least 2 months before the beginning of the protocol. The waist-to-hip ratio was $1.0 \pm 0.1$. None of them was on regular medication and showed known complications of obesity such as established hypertension, diabetes or dyslipidaemia. All subjects were Caucasians. Percutaneous biopsies of the vastus lateralis muscle were performed as reported previously [8]. Six lean and seven obese subjects participated in a 5 day study protocol during which they received a $1045 \mathrm{~kJ} / \mathrm{d}$ diet. Three days before the beginning of the study, the subjects received a standardized diet (104 kJ/kg per day). The first series of biopsies was performed after an overnight fast before the beginning of the calorie restriction. The second series of biopsies was performed the morning of the sixth day of calorie restriction. Samples were immediately frozen in liquid nitrogen and stored at $-80^{\circ} \mathrm{C}$. All subjects had given written consent and the experimental protocols were approved by the ethics committee of Hospices Civils de Lyon.

$R N A$ preparation. Total RNA from skeletal muscle was prepared using guanidinium thiocyanate-phenol-chloroform extraction. The yield of total RNA was $0.22 \pm 0.2$ and $0.23 \pm$ $0.2 \mu \mathrm{g} / \mathrm{mg}$ muscle tissue (wet weight) in lean and obese subjects, respectively. The absorption ratios 260 to $280 \mathrm{~nm}$ were between 1.7 and 2.0. RNA integrity was verified on agarose gel electrophoresis. Total RNA was stored at $-80^{\circ} \mathrm{C}$.

Quantification of mRNAs. Human UCP3 mRNAs were quantified by RT-competitive PCR. UCP3 ${ }_{\mathrm{L}}$ (390 nt-long) and $\mathrm{UCP}_{\mathrm{S}}$ (436 nt-long) cDNA fragments were obtained by RT-PCR on human skeletal muscle total RNA using $\mathrm{UCP} 3_{\mathrm{T}} \mathrm{S}$ $\left(5^{\prime}\right.$-ATGGACGCCTACAGAACCAT- $\left.3{ }^{\prime}\right)$ as sense primer and, UCP $3_{\text {L AS }}\left(5^{\prime}\right.$-TACGAACATCACCACGTTCC-3') or $\mathrm{UCP}_{\mathrm{S}} \mathrm{AS}$ ( $5^{\prime}$-TCACCGCTACATCCCAGGTT-3'), respectively, as antisense primers (Fig.1A). The two competitor
A
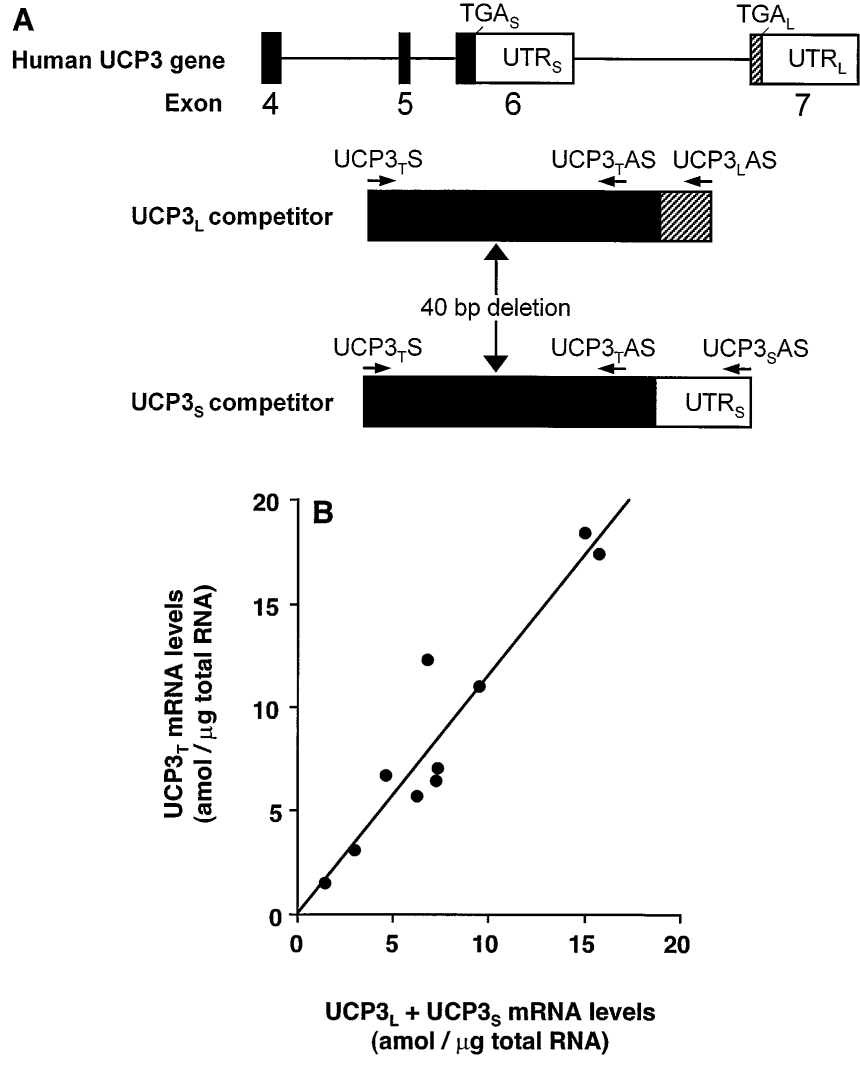

Fig. 1 A, B. Determination of the levels of UCP3 transcripts using RT-competitive PCR. A Scheme representing the strategy used to quantify the mRNA levels of UCP3 long $\left(\mathrm{UCP} 3_{\mathrm{L}}\right)$ and short $\left(\mathrm{UCP}_{\mathrm{S}}\right)$ form transcripts. The $3^{\prime}$ region (exons 4 to 7) of the human UCP3 gene is represented above with the $3^{\prime}$ untranslated regions (UTR) and stop codons (TGA) for the two forms. $\mathrm{UCP}_{\mathrm{L}}$ and $\mathrm{UCP} 3_{\mathrm{S}}$ competitor DNAs are shown below the gene structure with the position of a $40 \mathrm{bp}$ deletion made to discriminate PCR products amplified from cDNA and competitor DNA. The sense (S) and antisense primers (AS) are represented as arrows. Reverse transcription were performed using $\mathrm{UCP} 3_{\mathrm{T}} \mathrm{AS}, \mathrm{UCP} 3_{\mathrm{L}} \mathrm{AS}$ or $\mathrm{UCP} 3_{\mathrm{S}} \mathrm{AS}$ primers to quantify total $\mathrm{UCP} 3, \mathrm{UCP} 3_{\mathrm{L}}$ and $\mathrm{UCP} 3_{\mathrm{S}} \mathrm{mRNAs}$, respectively. These antisense primers were used in separate reactions with a common sense primer $\left(\mathrm{UCP}_{\mathrm{T}} \mathrm{S}\right)$ to PCR amplify the different cDNAs in the presence of increasing concentrations of competitor DNAs. B Plot of the sum of $\mathrm{UCP} 3_{\mathrm{L}}$ and $\mathrm{UCP} 3_{\mathrm{S}}$ mRNA levels vs total UCP3 $\left(\mathrm{UCP}_{\mathrm{T}}\right)$ mRNA levels. Determination of mRNA levels was performed in skeletal muscle of five lean and five obese subjects

DNAs were obtained by a deletion of $40 \mathrm{bp}$ using a two step polymerase chain reaction overlap extension method. Each competitor could be used to quantify total UCP3 mRNA levels (i.e. levels of the long plus the short form transcripts) using $\mathrm{UCP} 3_{\mathrm{T}} \mathrm{S}$ as sense primer and $\mathrm{UCP} 3_{\mathrm{T}} \mathrm{AS}\left(5^{\prime}-\mathrm{CTGGGCCAC-}\right.$ CATCTTTATCA-3') as antisense primer. Identity of the four constructs to published sequences were checked by automatic DNA sequencing (Applied biosystems). RT-competitive PCR was performed as described [8].

Statistical analysis. Values are given as means \pm SEM. The Wilcoxon nonparametric test for paired values was used for comparisons before and during fasting. The nonparametric $U$ Mann-Whitney test for unpaired values was used for compari- 

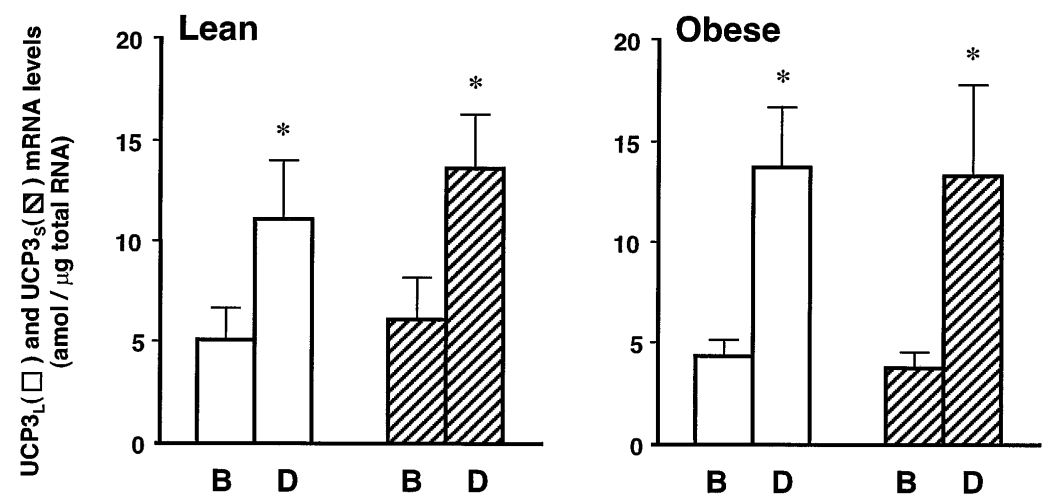

Fig. 2. Effect of 5 days of calorie restriction on $U C P 3_{L}$ and $\mathrm{UCP} 3_{\mathrm{S}}$ mRNA levels in skeletal muscle of six lean and seven obese subjects. B, before calorie restriction; D, during calorie restriction. *, $p<0.05$

sons between groups of subjects. In some cases, simple regression analysis was performed. Statistical calculations were performed with a software statistical package (Statview, Abacus Concepts, SAS Institute, San Francisco, CA, USA). The threshold of significance was $p$ less than 0.05 .

\section{Results}

Two competitor DNAs were constructed to measure $\mathrm{UCP}_{\mathrm{L}}$ and $\mathrm{UCP}_{\mathrm{S}}$ mRNA levels (Fig. 1A). To ensure the validity of the quantification, we simultaneously quantified $\mathrm{UCP} 3_{\mathrm{L}}, \quad \mathrm{UCP} 3_{\mathrm{S}}$ and total UCP3 mRNA levels in skeletal muscle from five lean and five obese subjects. A direct quantification of total UCP3 mRNA level was performed using either $\mathrm{UCP} 3_{\mathrm{L}}$ competitor DNA or $\mathrm{UCP} 3_{\mathrm{S}}$ competitor DNA and, $\mathrm{UCP} 3_{\mathrm{T}} \mathrm{S}$ and $\mathrm{UCP} 3_{\mathrm{T}} \mathrm{AS}$ primers. A good correlation $(r=0.95, p=0.0001)$ was found between the sum of $\mathrm{UCP}_{\mathrm{L}}$ and $\mathrm{UCP} 3_{\mathrm{S}} \mathrm{mRNA}$ levels and a direct determination of total UCP3 mRNA levels using $\mathrm{UCP}_{\mathrm{S}}$ competitor DNA (Fig. 1B). Total UCP3 mRNA levels were not different when $\mathrm{UCP}_{\mathrm{L}}$ competitor DNA was used (data not shown).

The levels of $\mathrm{UCP}_{\mathrm{L}}$ and $\mathrm{UCP} 3_{\mathrm{S}}$ mRNAs were compared in nine lean and seven obese subjects. No difference was found between the two groups for $\mathrm{UCP}_{\mathrm{L}}(4.0 \pm 1.2$ and $4.4 \pm 1.0 \mathrm{amol} / \mu \mathrm{g}$ total RNA in lean and obese subjects, $p=0.4)$ and $\mathrm{UCP}_{\mathrm{S}}(5.2 \pm$ 1.5 and $3.8 \pm 0.8 \mathrm{amol} / \mu \mathrm{g}$ total RNA in lean and obese subjects, $p=0.8)$ mRNA expression. When the 16 subjects were pooled into one group, $\mathrm{UCP}_{\mathrm{L}}(4.1 \pm$ $0.8 \mathrm{amol} / \mu \mathrm{g}$ total RNA) and $\mathrm{UCP}_{\mathrm{S}}(4.6 \pm 0.9 \mathrm{amol} /$ $\mu \mathrm{g}$ total RNA) mRNA levels were not significantly different $(p=0.8)$ suggesting that alternative splicing and use of polyadenylation signals occur $50 \%$ of the time.

The regulation of $\mathrm{UCP} 3_{\mathrm{L}}$ and $\mathrm{UCP} 3_{\mathrm{S}}$ transcript expression was studied in six lean and seven obese sub-

jects maintained on calorie restriction for 5 days. BMI decreased from $22 \pm 0.6$ to $21 \pm 0.5 \mathrm{~kg} / \mathrm{m}^{2}$ $(p<0.05)$ in lean subjects and from $35.3 \pm 1.7$ to $34.3 \pm 1.5 \mathrm{~kg} / \mathrm{m}^{2}(p<0.02)$ in obese patients. Fasting glycaemia decreased from $4.8 \pm 0.1$ to $3.7 \pm$ $0.3 \mathrm{mmol} / 1(p<0.05)$ in lean subjects and from $5.0 \pm$ 0.2 to $4.2 \pm 0.2 \mathrm{mmol} / 1 \quad(p<0.02)$ in obese subjects. Fasting plasma insulin concentrations decreased from $34 \pm 2$ to $30 \pm 1 \mathrm{pmol} / \mathrm{l}(p<0.05)$ in lean subjects and from $87 \pm 18$ to $46 \pm 4 \mathrm{pmol} / \mathrm{l}(p<0.05)$ in obese subjects. Plasma NEFA levels increased during the hypocaloric diet in the lean (from $422 \pm 69$ to $882 \pm 126 \mu \mathrm{mol} / 1, p<0.05$ ) and obese (from $629 \pm 45$ to $857 \pm 43 \mu \mathrm{mol} / 1, p<0.02$ ) groups. Daily urinary free cortisol levels did not change during the 5-day calorie restriction (data not shown). Plasma free triiodothyronine levels decreased in the lean (from $5.1 \pm 0.3$ to $4.2 \pm 0.1 \mathrm{pmol} / 1, p<0.05)$ and obese (from $5.2 \pm 0.3$ to $4.7 \pm 0.4 \mathrm{pmol} / 1, p=0.07$ ) groups. $\mathrm{UCP} 3_{\mathrm{L}}$ and $\mathrm{UCP} 3_{\mathrm{S}}$ mRNA levels increased in lean and obese subjects (Fig.2). In the two groups, $\mathrm{UCP} 3_{\mathrm{L}}$ mRNA levels were not significantly different from $\mathrm{UCP} 3_{\mathrm{S}}$ mRNA levels $(p>0.3)$ neither before nor during fasting. Before and during fasting, the level of each transcript did not differ between lean and obese subjects $(p>0.4)$.

\section{Discussion}

In the present study, we have analysed the expression of the two mRNA transcripts generated by the human UCP3 gene in obese patients and lean subjects matched for age. $\mathrm{UCP} 3_{\mathrm{L}}$ and $\mathrm{UCP} 3_{\mathrm{S}}$ mRNAs are expressed in equal amounts in the vastus lateralis muscle. The biological significance of this observation will need further investigation at the protein level. The domain absent in $\mathrm{UCP} 3_{\mathrm{S}}$ may be important for the correct insertion of the protein in the plasma membrane since it contains the putative sixth transmembrane domain $[3,6]$. Therefore, $\mathrm{UCP} 3_{\mathrm{S}}$ may not be stable and may not be expressed to a significant extent in the mitochondrial inner membrane. It is also possible that the protein show an increased uncoupling activity compared with $\mathrm{UCP}_{\mathrm{L}}$ because of 
the lack of a conserved motif that mediates inhibition of UCP1 uncoupling activity by purine nucleotides. Consequently, variation in the ratio between $\mathrm{UCP} 3_{\mathrm{L}}$ and $\mathrm{UCP} 3_{\mathrm{S}}$ could modulate skeletal muscle uncoupling activity.

The abundant and selective expression of UCP3 in human skeletal muscle suggests that it may be a mediator of thermogenesis [3-5,9]. An altered level of expression of $\mathrm{UCP} 3_{\mathrm{L}}$, and maybe of $\mathrm{UCP} 3_{\mathrm{S}}$, could contribute to an altered energy expenditure in obesity. In our study, this does not seem to be the case since $\mathrm{UCP} 3_{\mathrm{L}}$ and $\mathrm{UCP} 3_{\mathrm{S}}$ mRNA levels were no different between obese and lean people before fasting. Regulation of the levels of the two transcripts could occur during calorie restriction since we have shown that this condition results in an induction of total UCP3 mRNA expression [8]. A marked increase of $\mathrm{UCP} 3_{\mathrm{L}}$ and $\mathrm{UCP} 3_{\mathrm{S}}$ mRNA levels was observed during fasting in lean and obese subjects. The ratio between the two forms was not modified. These data suggest that there is no major alteration of UCP3 gene regulation at the level of transcription and alternative splicing in obesity. Obesity being a multifactorial disease, our data do not rule out possible alterations of UCP3 mRNA expression in subpopulations of obese patients and, associations between UCP3 transcript levels and some clinical parameters associated with obesity. Differences could also exist between lean and obese subjects at the levels of protein translation and regulation of uncoupling activity by cellular activators and inhibitors.

Calorie restriction provokes a complex physiological adaptation with numerous hormonal and metabolic changes that could explain the increase in skeletal muscle UCP3 gene expression. UCP3 mRNA levels are increased by in vivo treatment of rats with triiodothyronine and dexamethasone [5]. Since plasma free triiodothyronine level decreased and cortisol level did not change during the 5-day fasting protocol, these hormones do not seem to play a major role in UCP3 mRNA upregulation. We have shown that a 3-h insulin infusion does not modulate total UCP3 mRNA expression in human skeletal muscle [8] suggesting that the calorie restriction-induced decrease in insulinaemia does not contribute to UCP3 upregulation. It was recently proposed that the in- crease in rat skeletal muscle UCP3 mRNA levels observed during fasting [9] could be mediated by NEFA [10]. Further investigation is required to show whether the increase in NEFA levels occurring during fasting contributes to the upregulation of $\mathrm{UCP}_{\mathrm{L}}$ and $\mathrm{UCP} 3_{\mathrm{S}}$ mRNAs in humans.

Acknowledgements. The authors are grateful to Drs. J.P. Riou, M. Lafontan and N. Viguerie-Bascands for critical reading of the manuscript.

\section{References}

1. Fleury C, Neverova M, Collins S et al. (1997) Uncoupling protein-2: a novel gene linked to obesity and hyperinsulinemia. Nature Genet 15: 269-272

2. Gimeno RE, Dembski M, Weng X et al. (1997) Cloning and characterization of an uncoupling protein homolog. A potential molecular mediator of human thermogenesis. Diabetes 46: 900-906

3. Boss O, Samec S, Paolini-Giacobino A et al. (1997) Uncoupling protein-3: a new member of the mitochondrial carrier family with tissue-specific expression. FEBS Lett 408: 39-42

4. Vidal-Puig A, Solanes G, Grujic D et al. (1997) UCP3: an uncoupling protein homologue expressed preferentially and abundantly in skeletal muscle and brown adipose tissue. Biochem Biophys Res Commun 235: 79-82

5. Gong DW, He Y, Karas M et al. (1997) Uncoupling protein-3 is a mediator of thermogenesis regulated by thyroid hormone, beta3-adrenergic agonists, and leptin. J Biol Chem 272: 24129-24132

6. Solanes G, Vidal-Puig A, Grujic D et al. (1997) The human uncoupling protein-3 gene. Genomic structure, chromosomal localization, and genetic basis for short and long form transcripts. J Biol Chem 272: 25433-25436

7. Bouchard C, Pérusse L, Chagnon YC et al. (1997) Linkage between markers in the vicinity of the uncoupling protein 2 gene and resting metabolic rate in humans. Hum Mol Genet 6: 1887-1889

8. Millet L, Vidal H, Andreelli F et al. (1997) Increased uncoupling protein-2 and -3 mRNA expression during fasting in obese and lean humans. J Clin Invest 100: 2665-2670

9. Boss O, Samec S, Kühne F et al. (1998) Uncoupling protein-3 expression in rodent skeletal muscle is modulated by food intake but not by changes in environmental temperature. J Biol Chem 273: 5-8

10. Weigle DS, Selfridge LE, Schwartz MW et al. (1998) Elevated fatty acids induce uncoupling protein 3 expression in muscle. A potential explanation for the effect of fasting. Diabetes 47: 298-302 